[Araştırma Makalesi / Research Article]

\section{KUUA Kastamonu Eğitim Dergisi Kastamonu Education Journal}

Eylül 2019 Cilt:27 Sayı:6

kefdergi.kastamonu.edu.tr
Başvuru Tarihi/Received: 13.06.2018

Kabul Tarihi/Accepted: 17.02.2019

DOI: 10.24106/kefdergi.3153

\title{
Kavramsal Değişim Metinlerinin Sosyal Bilgiler Dersindeki Kavram Yanılgılarının Giderilmesine Etkisi ${ }^{1}$ \\ The Effect of Conceptual Change Texts on Overcoming The Misconceptions in the Social Studies Courses
}

\section{Öz}

\author{
Tekin ÇELIKKAYA ${ }^{2}$, Ramazan ŞARLAYAN ${ }^{3}$
}

Araştırmanın amacı, 7. sınıf öğrencilerinin "Türk Tarihinde Yolculuk" ünitesinde yer alan kavram yanılgıları üzerinde, kavramsal değişim metinlerinin etkisini incelemektir. Araştırmanın çalışma grubu, Kırşehir il merkezinde bulunan X ortaokulunda öğrenim gören 7/A ve 7/C sınıfi öğrencilerinden oluşturulmuştur. Bu sınıflardan 7/A deney (n:22), 7/C kontrol grubu (n:27) olarak belirlenmiştir. Araştırmada yöntem olarak, eşitlenmemiş kontrol gruplu desen kullanılmıştr. Kavramlar belirlenirken 7. sınıf sosyal bilgiler öğretmen kılavuz kitabı, Türk Tarihinde Yolculuk ünitesinde öğrencilere kazandırılması hedeflenen kavramların yer aldığı, öğrencilerin kavramların anlamlarını kısa yazılı cevaplar olarak verebilecekleri şekilde düzenlenmiş açık uçlu soru formu kullanılmıştr. Öğrencilerin formdaki kavramlara verdikleri cevaplar değerlendirilirken ders kitabında kavramlarla ilgili yapılan açıklamalar ile Büyük Türkçe Sözlük'teki açıklamalar göz önünde bulundurulmuştur. Öğrencilerin verdikleri cevaplar; kavramı doğru anlama, kavram yanılgısı ve cevapsız şeklinde tasnif edilmiş, yüzde ve frekans değerleri alınarak yorumlanmış sonuçlara göre en fazla kavram yanılgısı görüldüğü tespit edilen 6 kavram belirlenmiştir. Araştırmada veri toplamak amacıyla; araştırmacı tarafindan geliştirilen Kavram Başarı Testi (KBT) kullanılmıştır. Deney ve kontrol grubu öğrencilerinin öntest ve sontest puanlarının analizi için SPSS 20 paket programı kullanılarak yüzde, örnekleme alınan birey sayısı (n), aritmetik ortalama ile "bağımsız gruplar" için t-testi kullanılmıştır. Yapılan analizler sonucunda, öntestte, Kavram Başarı Testi puanları açısından, deney ve kontrol grupları arasında istatistiksel olarak anlamlı bir farkın olmadığı, sontestte ise deney grubunun lehine anlamlı bir farkın olduğu belirlenmiştir. Araştırmanın sonucunda, çă̆, estetik, fetih, gâzâ, ıslahat, iskân kavramlarıyla ilgili öğrencilerde mevcut bulunan kavram yanılgılarının giderilmesinde ve başarılarında, kavramsal değişim yaklaşımına dayalı öğretimin ve materyallerin programa dayalı öğretim etkinliklerine göre daha etkili olduğu belirlenmiştir.

Anahtar Kelimeler: Kavramsal değişim metni, kavram yanılgısı, sosyal bilgiler

\section{Abstract}

The aim of the research is to analyze the effects of conceptual change texts on the misconceptions in "Journey to Turkish History" unit of $7^{\text {th }}$ grade students. The study group of the research was formed from $7 / A$ and $7 / C$ students at $X$ secondary school which is in the center of Kırsehır. From these classrooms $7 / A(n: 22)$ was experimental and the $7 / C$ (n: 27). was control group In the study, unequal control grouped design was used. While the concepts were being defined, a questionnaire form was used in which $7^{\text {th }}$ class social studies teacher textbook included concepts targeted to students in the Journey to Turkish History unit and students could give the meaning of concepts as short written answers. While the answers given by the students to the concepts in the form were evaluated, the explanations made about the concepts in the textbook and the statements of the Great Turkish Dictionary were taken into account. The answers given by the students were classified as correct understanding of concepts, misconceptions and misses, and the percentage and frequency values were taken and 6 concepts were found to be the most misconceptions according to the interpreted results in order to collect data in the study, Concept Achievement Test (CAT) developed by researcher were used. The percentage, the number of the sample taken $(n)$, the t-test for the independent groups in with arithmetic mean were performed using the SPSS 20 package program for the analysis of pretest and posttest scores of the students in the experimental and control groups. As a result of the analysis, it was determined that there was no statistically significant difference between experimental and control groups in terms of Achievement Test and Concept Test scores in pre - test, and there was a meaningful difference in favor of experimental group in post-test. As a result of the research, it has been determined that teaching and materials based on the conceptual change approach are more effective in eliminating the misconceptions that exist in the students related to the concepts of age, aesthetics, conquest, holy war, reform and settlement compared to program based activities.

Keywords: Conceptual change text, misconceptions, social studies

1. İkinci yazarın “Kavramsal Değişim Metinlerinin Sosyal Bilgiler Dersindeki Kavram Yanılgılarının Giderilmesine Etkisi” adlı Yüksek Lisans tez çalışmasından türetilmiştir.

2. Kırşehir Ahi Evran Üniversitesi, Eğitim Fakültesi, Türkçe ve Sosyal Bilgiler Eğitimi Bölümü, Kırşehir, Türkiye; https://orcid.org/0000-0001-5684-6492

3. Erol Güngör Ortaokulu Sosyal Bilgiler Öğretmeni, Kırşehir, Türkiye; https://orcid.org/0000-0002-6215-9661

Atıf / Citation: Çelikkaya, T., \& Şarlayan, R. (2019). Kavramsal değişim metinlerinin sosyal bilgiler dersindeki kavram yanılgılarının giderilmesine etkisi. Kastamonu Education Journal, 27(6), 2403-2412. doi:10.24106/kefdergi.3153 


\section{Extended Abstract}

Aim: In this study, students' level of understanding the concepts mentioned in the unit were determined and misconceptions about the concepts were detected. In addition to this, it is important that the misconceptions in the study and the teaching approaches and materials used for overcoming misconceptions are useful for the teachers and the researchers who will work on this issue.The aim of the research is to analyze the effects of conceptual change texts in the conceptual change approach on the misconceptions in 7th grade students "Journey to Turkish History" unit. Within the scope of this aim, the following main questions will be answered in the investigation:

The current misconceptions of experimental and control group students about the concepts of age, aesthetics, conquest, ghazal, reform and settlement;

1. Is there a significant difference between pre-test scores?

2. Is there a significant difference between the post- test scores?

3. Is there a significant difference between pre-test and post-test scores?

Method: The study group of the research was formed from 7/A and 7/C students at $X$ secondary school which is in the center of Kırsehir. From these classrooms 7/ A (n: 22) was experimental and the $7 / C$ ( $n: 27)$ was control group. In the study, unequal control grouped design was used. While the concepts were being defined, a questionnaire form was used in which 7th class social studies teacher textbook included concepts targeted to students in the Journey to Turkish History unit and students could give the meaning of concepts as short written answers. While the answers given by the students to the concepts in the form were evaluated, the explanations made about the concepts in the textbook and the statements of the Great Turkish Dictionary (TDK, 2016) were taken into account. The answers given by the students were classified as correct understanding of concepts, misconceptions and misses, and the percentage and frequency values were taken and 6 concepts were found to be the most misconceptions according to the interpreted results. While in the experimental group, conceptual change texts were used in order to eliminate students' misconceptions about the concepts of age, aesthetics, conquest, holy war, reform, settlement, a program based teaching approach was applied in eliminating the fallacy of these concepts in the control group.

Table 1. Pre-test-Post-test Control Group Pattern

\begin{tabular}{cccc}
\hline Groups & Pre-test & Experimental Process & Post-test \\
\hline $\mathrm{D}$ & $\ddot{\mathrm{O}}_{1}$ & $\mathrm{X}$ & $\mathrm{S}_{1}$ \\
$\mathrm{~K}$ & $\ddot{\mathrm{O}}_{2}$ & $\mathrm{Y}$ & $\mathrm{S}_{2}$ \\
\hline
\end{tabular}

When the Table 1 is examined, $\mathrm{D}$ experimental group, $\mathrm{K}$ control group, pre-test and post-test measurements of Ö1 and S1 experimental group, pre and post test measurements of Ö2 and S2 control group, X is the conceptual change texts applied to the experimental group, and $Y$ is the teaching and learning process based on the social studies program applied to the control group shows.

The information about the design of the research is given in Table 2. In the pre-test phase, the concept achievement test developed by the researcher was applied to the groups.In the experimental process section of the research, conceptual change texts were applied developed for the concepts of age, aesthetics, conquest, gaza, reform, settlement in the $7^{\text {th }}$ grade Social Studies "Journey in Turkish History"3.unit. In the control group, the lessons were taught with instruction based curriculum. In the final test, the process was completed by applying the concept achievement test used in the pre-test to the students.

Table 2. Experimental Design of the Study

\begin{tabular}{cccc}
\hline Groups & Pre-test & Experimental Process & Post-test \\
\hline Experiment & Concept Achievement Test & Supported Lessons with Developed KDM & Concept Achievement Test \\
Control & Concept Achievement Test & Teaching with Social Studies Program & Concept Achievement Test
\end{tabular}

In order to collect data in the study, Concept Achievement Test (CAT) developed by researcher were used. The percentage, the number of the sample taken $(n)$, the t-test for the est independent groups in with arithmetic mean were performed using the SPSS 20 package program for the analysis of pretest and posttest scores of the students in the experimental and control groups. As a result of the analysis, it was determined that there was no statistically significant difference between experimental and control groups in terms of Achievement Test and Concept Test scores in pre - test, and there was a meaningful difference in favor of experimental group in post-test.

Discussion and Conclusion: As a result of the research, it has been determined that teaching and materials based on the conceptual change approach are more effective in eliminating the misconceptions that exist in the students related to the concepts of age, aesthetics, conquest, holy war, reform and settlement compared to program based activities. 


\section{Giriş}

Öğretim programlarında kavramlar önemli bir yere sahiptir. Özellikle Sosyal Bilgiler dersinin amaçlarını gerçekleştirilebilmesi için bu programda yer alan kavramların her öğrencinin zihninde aynı anlamı oluşturabilecek şekilde geliştirilmesi gerekir (Doğanay, 2005:271). İlköğretim Sosyal Bilgiler dersinin amaçlarından biri de öğrencilerin ünitelerle ilgili çeşitli sosyal kavramları anlayabilmeleridir (Yazıcı ve Samancı, 2003). Sosyal bilgiler öğretiminde kavramları etkili bir şekilde öğrencilere kazandırmak için öncelikle o kavramla ilgili olarak öğrencilerin önbilgilerini ve varsa yanlış algılamalarını tespit etmek gereklidir. Bu konuda çeşitli yöntemler (açık uçlu sorular, tartışma etkinliği, resim çizme, kelime ilişkilendirme vb.) kullanmak mümkündür. Kavram öğretim sürecinde kullanılmak üzere gerekli materyallerin sağlanması da önemlidir. Bu materyaller öğretilmesi planlanan kavrama göre değişmekle beraber fotoğraf, cd, modeller, bulmacalar vb. olabilir (Alkış, 2014:78).

Bireyler küçük yaşlarda fiziksel ve sosyal dünyayı kendi deneyimleri ile tanıyarak, zihinlerinde gerçek bilimsel düşüncelerden farklı bir düşünce süreci oluşturmaktadırlar. Onların zihinlerinde nesnelere ve olaylara ait oluşturdukları kavramlar, bilimsel olarak kabul görmüş kavramlardan farklılık gösteriyorsa bu durum kavram yanılgılarına neden olmaktadır (Borazan, 2008:14). Kavram yanılgıları, klasik öğretim tekniklerine dirençli, sabit ve yaygın olarak bilimsel kavramlarla örtüşmeyen fikirler olarak tanımlanabilir. Kavram yanılgılarının temel nedenleri; öğrenci faktörleri (önceden gerekli olan bilginin eksikliği, önyargılar, motivasyon ve ilgi eksikliği, bilimsel konularda günlük konuşma dilinin kullanılması), öğretmen faktörleri (yetersiz konu bilgisi, kavramların kategorilendirilmesi, detaylara fazla önem verme) ve ders kitapları faktörleri (öğretme sıralaması, çok fazla hata ve yanlış bilgi içermesi, şekil ve örneklerin eksikliği, konular arasında bağlant eksikliği) olarak sıralanabilir (Eyidoğan ve Güneysu, 2002:8). Bireylerin bir bilimsel alana ilişkin fikirler üretebilmeleri için de, öncelikle o alana ilişkin kavramları kazanmış olmaları ve var olan kavram yanılgılarının giderilmesi gerekmektedir (Sever, Budak ve Yalçınkaya, 2009:20).

Kavram yanılgılarını düzeltmeye yönelik çalışmaya başlarken öncelikle, öğrencilerin bireysel olarak veya sınıfin çoğunluğunun sahip olduğu kavram yanılgılarının belirlenmesi gereklidir. Birçok araştırmacı, bilim adamı ve öğretmen tarafindan değişik araştırmalar sonucu tespit edilmiş olan çok sayıda kavram yanılgısı düzenlenerek konulara göre gruplandırılmıştır (Baloğlu, 2003; Borazan, 2008; Çaycı, 2007; Elvan, 2012; Kılıçoğlu, 2011). Yine öğrencilerin sahip olduğu kavram yanılgılarını tespit etmek için hemen hemen her konuda kavramsal testler geliştirilmiştir. Ayrıca tartş̧ma ortamı oluşturarak ve öğrencilerle görüşme yoluyla kavram yanılgılarının tespitine yönelik çalışmalarda bulunmaktadır. Öğretmen öğrencilerdeki kavram yanılgılarını tespit etmek istediğinde, bu testleri ve araştrmaları kullanmadan bile, sadece öğrenciyi dinleyerek de bu kavram yanılgılarının birçoğunu belirleyebilir (Ay, 2011:29).

Kavramlar bilgilerin yapı taşları olduklarına göre, öğrencilerin bilgiyi yapılandırma sürecinde öncelikle kavramları sağlıkı bir biçimde yapılandırması gerekir. Bu noktadan hareketle, kavram öğretiminde iki önemli yaklaşımın damgasının bulunduğu belirtilebilir. Bunlardan ilki öğrenme döngüsü diğeri ise kavramsal değişim yaklaşımıdır (Çaycı, 2009:311). Kavramsal değişimin gerçekleşmesi için, öğrencilerin mevcut bilgilerinin ortaya çıkarılması gereklidir. Öğretmen tarafindan sunulan bir kavram sınıftaki öğrencilerin bir kısmına makul ve mantıklı gelebilir, ancak diğerleri için aynı kavram mantıklı olmayabilir. Hatta önceki bilgileri ile ters düşebilir. Başka bir ifadeyle, aynı konu farklı öğrenciler için farklı öğretim stratejileri gerektirebilir (Yılmaz, 2010: 17). Öğrencilerde öğrenmenin anlamlı olması ve var olan yanılgıların giderilmesi için analoji, kavram haritaları, kavram karikatürleri ve kavramsal değişim metinleri kullanılabilir.

Kavramsal değişim metinleri öğrencilerde bulunan kavram yanılgılarını gidermede kullanılan yöntemlerden biridir. Bu metinler öğrencilerin zihinlerinde var olan kavram yanılgılarını kavramların bilimsel ifadeleriyle uyumlu hale getirmeyi ve bu yanılgıları gidermeyi amaçlayan metinlerdir. Kavramsal değişim metinleri hazırlanırken öncelikle öğrencilerin konuyla ilgili var olan kavram yanılgıları belirlenir. Daha sonra öğrencilerde kavramlarla ilgili olarak var olan bu yanılgılar kavramların bilimsel olarak kabul edilen açıklamalarıyla aralarındaki farklar ortaya konur ve bunlar örneklerle ifade edilir. Daha sonra öğrencilerin kavramları açıklamalarındaki yanlışlıklarını farkına varmaları için onlara sorular sorulur (Hynd, 2001; Akt. Kılıçoğlu, 2011:31). Bununla öğrenciler için zihinlerinde var olan kavram yanılgıları ile sosyal bilgiler kavramları arasındaki uyumsuzlukların ve yanılgıların farkına vardıılmaları sağlanmış olur.

Literatür incelemelerinde Sosyal Bilgiler alanında (Akşit,2016;Kılıçoğlu,2011) kavramsal değiş̧im metinleri ile ilgili fazla çalışma olmadığı, kavramsal değişim metinleri ile ilgili daha çok Fen Bilimleri alanında çalışmalar (Hacımustafaoğlu,2015; Kılıç Alemisoğlu,2014; Arıkurt, 2014;Topuz, 2014;Özdemir, 2012;Sarı Ay, 2011;Demirci, 2011;Mutlu, 2011) olduğu görülmektedir.

7. sınıf Sosyal Bilgiler dersi "Türk Tarihinde Yolculuk" ünitesi, özellikle tarih disiplinine ait kavramların ağırlıkta olduğu kültür ve miras aktarımı gibi tarih konularının öğrenilmesi açısından önemli bir yere sahiptir. Bu ünitede yer alan tarihi konuların soyut olması öğrencilerin konuların içerisinde yer alan kavramları öğrenmelerini güçleştirmektedir. Kavram 
öğrenmede yaşanan güçlükler ise konuların anlaşılmasını zorlaştırmaktadır.

Bu araştırmada öğrencilerin ünitede geçen kavramları ilişkin sahip oldukları kavram yanılgıları tespit edilmiştir. Bununla birlikte çalışmada belirlenen yanılgılar ve bu yanılgıları gidermede kullanılan öğretim yaklaşımı ve materyallerinin, öğretmenlere ve bu konuda çalışma yapacak araştırmacılara faydalı olması açısından önemlidir.

Araştırmanın amacı, 7. sınıf öğrencilerinin "Türk Tarihinde Yolculuk" ünitesinde yer alan kavramlara ilişkin kavram yanılgıları üzerinde, kavramsal değişim metinlerinin etkisini incelemektir. Bu amaç çerçevesinde, araştırmada başlıca şu sorulara cevap aranacaktr;

Çağ, estetik, fetih, gazâ, ıslahat ve iskân kavramlarına ilişkin deney ve kontrol grubu öğrencilerinin mevcut kavram yanılgılarının;

1. Ön test puanları arasında anlamlı bir fark var mıdır?

2. Son test puanları arasında anlamlı bir fark var mıdır?

3. Ön test-son test puanları arasında anlamlı bir fark var mıdır?

\section{Yöntem}

7. Sınıf Sosyal Bilgiler Türk Tarihinde Yolculuk ünitesinde geçen kavramlardan kavram yanılgıları tespit edilen çağ, estetik, fetih, gâzâ, ıslahat, iskân kavramlarına yönelik yanılgıların giderilmesinde kavramsal değişim metinlerinin etkisi üzerine yapılan bu araştırmada nicel araştırma yaklaşımı kapsamında "Eşitlenmemiş kontrol gruplu desen" kullanılmıştr. Bu modelin simgesel görünümü Tablo 1'de verilmiştir. Eşitlenmemiş kontrol gruplu modelde aslında, ön test-son test kontrol grupların eşitlenmeleri için özel bir çaba harcanmamaktadır. Ancak, katılanların benzer nitelikte olmalarına olabildiğince özen gösterilir. Gruplardan hangisinin deney hangisinin kontrol grubu olacağı random yoluyla kararlaştırılır (Karasar, 2008: 102).

Tablo 1. Ön test-Son test Kontrol Gruplu Desen

\begin{tabular}{cccc}
\hline Gruplar & Ön test & Deneysel işlem & Son test \\
$\mathrm{D}$ & $\ddot{O}_{1}$ & $\mathrm{X}$ & $\mathrm{S}_{1}$ \\
$\mathrm{~K}$ & $\ddot{O}_{2}$ & $\mathrm{Y}$ & $\mathrm{S}_{2}$ \\
\hline
\end{tabular}

Tablo 1 incelendiğinde D deney grubunu, K kontrol grubunu, Ö1ve S1 deney grubunun ön test ve son test ölçümlerini, Ö2 ve S2 kontrol grubunun ön test ve son test ölçümlerini, $X$ deney grubuna uygulanan kavramsal değişim metinleri (KDM) ile dersin işlenişini ve $\mathrm{Y}$ ise kontrol grubuna uygulanan sosyal bilgiler programına dayalı öğretim ile ders işlenişini göstermektedir.

Tablo 2. Araştırmanın Deneysel Deseni

\begin{tabular}{llcc}
\hline Gruplar & Ön test & Deneysel İşlem & Son test \\
\hline Deney & Kavram Başarı Testi & Geliştirilen KDM ile Desteklenen Ders İ̧̧lenişi & Kavram Başarı Testi \\
\hline Kontrol & Kavram Başarı Testi & Sosyal Bilgiler Programına Dayalı Öğretim ile Ders İşlenişi & Kavram Başarı Testi \\
\hline
\end{tabular}

Araştırmanın deseni ile ilgili bilgilere Tablo 2'de yer verilmiştir. Ön test aşamasında gruplara konuyla ilgili olarak araştrrmacı tarafindan geliştirilmiş olan kavram başarı testi uygulanmıştır. Araştırmanın deneysel işlem bölümünde deney gruplarında araştırmacı tarafindan 7. sınıf Sosyal Bilgiler dersi "Türk Tarihinde Yolculuk" ünitesinde geçen çağ, estetik, fetih, gazâ, ıslahat, iskân kavramlarına yönelik geliştirilen kavramsal değişim metinleri ( bu metinler aktif öğrenme içinde olsa bile 7.sınıf sosyal bilgiler kitabının hiçbir konu ve bölümünde kavramsal değişim metinlerinin kullanımına ilişkin bir durum söz konusu değildir) uygulanmıştr. Kontrol grubunda ise dersler programa dayalı öğretim (öğretmen kılavuz kitabındaki konunun işlenişi bölümündeki uygulama esas alınarak soru-cevap, görsel materyal kullanımı vb. ) ile işlenmiştir. Son testte ise öğrencilere ön testte kullanılan kavram başarı testi uygulanarak süreç tamamlanmıştır.

\section{Çalışma grubu}

Araştırmanın çalışma grubunu, Kırşehir il merkezinde bulunan X ortaokulunun 7. sınıfina devam eden 2 farklı şubedeki toplam 49 öğrenci oluşturmaktadır. Deney grubu olan 7/A şubesi 10 erkek 12 kız, kontrol grubu olan 7/C şubesi 15 erkek 12 kız öğrenciden oluşmaktadır. Genel olarak, deney ve kontrol grubundaki öğrenciler sayı, yaş ve not ortalamaları gibi özellikler açısından benzerlik göstermektedir. Bu ilköğretim okulunda toplam 5 yedinci sınıf bulunmaktadır. Basit seçkisiz örnekleme yöntemi ile seçilen bir deney ve bir kontrol grubu belirlenmiştir. Uygulama 2015-2016 eğitim-öğretim yılının birinci döneminde gerçekleștirilmiștir.

| Kastamonu Eğitim Dergisi, 27(6), 2019| 


\section{Veri toplama araçları}

Öncelikle hangi kavramlarda yanılgı olduğunu belirlemek için, Kırşehir il merkezinde örneklem dışında tutulan 2 ortaokuldaki 174 öğrenciye 7. Sınıf Sosyal Bilgiler Türk Tarihinde Yolculuk ünitesinde geçen kavramlara yönelik kavram yanılgılarını tespit etmek üzere kavramların anlamlarını kısa yazılı cevaplar olarak verebilecekleri şekilde düzenlenmiş açık uçlu soru formu kullanılmıştır. Kavramlarda yanılgı olup olmadığını belirlemek için kavramların sosyal bilgiler programında ve Büyük Türkçe Sözlük'teki (TDK, 2016) geçen tanımları dikkate alınmıştır.

Tarihi kavramlardan çağ, estetik, fetih, gazâ, ıslahat, iskân kavramları coğrafi kavramlardan ise Coğrafi Konum ve Harita kavramlarında kavram yanılgısına rastlanmıştır. Kavramlarda yanılgı olup olmadığını belirlemek için kavramların sosyal bilgiler programında ve Büyük Türkçe Sözlük 'teki (Türk Dil Kurumu [TDK], 2016) geçen tanımları dikkate alınmıştr. Örneğin; Gaza kavramının TDK(2016) Büyük Türkçe Sözlükteki anlamı "Gâzâ, İslam dinini korumak veya yaymak amacıyla Müslüman olmayanlara karşı yapılan kutsal savaşa verilen isimdir." iken kavram yanılgısı olduğu belirlenen öğrenciler gaza kavramını "Kolaylık, sonu kötü biten olay, kışkırtmak, bir tür sıvı yakıt, ölüm, kazanmak, iki aracın birbirine çarpması, bir ilin ilçesi. "şeklinde tanımlamışlardır Ünitenin ağırlıklı olarak tarihi konuları kapsadığı için coğrafi kavramlardaki yanılgı olan kavramlar kapsam dışında tutulmuştur. Kavram yanılgısı olduğu belirlenen bu alt kavramla ilgili kavramsal değişim metinleri ve 34 maddeden oluşan kavram başarı testi hazırlanmıştır.

Hazırlanan kavram başarı testi uzman görüşleri sonrasında yapılan düzeltmelerden sonra 8. sınıf öğrencilerine (200) uygulanmış olup bu ön uygulamada testin KR-20 güvenirlik katsayısı .83 olarak bulunmuştur. Değerlendirme sonucunda soru sayısı 26'ya düşürülmüştür. 26 sorudan oluşan kavram başarı testi çalışma sürecinde öntest ve sontest olarak kullanılmıştır.

Araştırmada geliştirilen kavram başarı testi değerlendirildiğinde testin ortalama güçlüğünün 0.51 olduğu görülmektedir. Bu anlamda testin madde güçlük indeksi açısından uygun ve kullanılabilir bir değere sahip olduğu söylenebilir.

Madde güçlük indeksine göre;

$\checkmark \quad 1,3,4,9,10$ ve 27 . sorular kolay oldukları için,

$\checkmark$ 26. soru zor olduğu için,

$\checkmark \quad$ Madde ayırt edicilik gücüne göre;

$\checkmark$ 13. soru ise ayırt ediciliği düşük olduğu için testten çıkarılmıştır.

26 sorudan oluşan kavram başarı testi öntest ve sontest olarak kullanılmak üzere iki aşamalı teste dönüştürülmüştür. İki aşamalı teste öğrenci doğru cevabı işaretleme ile birlikte buna ek olarak sorunun altında "Çünkü" ile başlayan cevabın gerekçesini yazmaktadır. İki aşamalı testlerin değerlendirilmesinde Karataş, Köse ve Coştu (2003:62) tarafindan belirlenen sınıflama ve puanlama sistemi kullanılmıştır (Tablo 3).

Tablo 3 . İki Aşamalı-Açık Uçlu Soruların Analizinde Kullanılan Değerlendirme

\begin{tabular}{lllc}
\hline Anlama & Düzeyleri & $\begin{array}{c}\text { Açıklama Değerlendirme Kriterleri } \\
\text { Puan }\end{array}$ & Puan \\
\hline Doğru Gerekçe & Geçerliliği olan gerekçenin bütün yönlerini içeren cevaplar & Doğru Cevap - Doğru Gerekçe \\
Doğru Gerekçe & Doğru olmayan bilgiler içeren cevaplar & Yanlış Cevap - Doğru Gerekçe \\
Yanlış Gerekçe & İlgisiz, açık olmayan cevap verme & Doğru Cevap - Yanlış Gerekçe \\
Yanlış Gerekçe & Boş bırakma/ Yanlış Cevap & Yanlış Cevap - Yanlış Gerekçe & 2 \\
\hline
\end{tabular}

Bu araştırmada kullanılan kavramsal değişim metinlerinin hazırlanmasında Posner, Strike, Hewson ve Gertzog (1982) tarafindan belirtilen kavramsal değişim yaklaşımı esas alınmıştır. Bu yaklaşımda, yetersizlik (dissatisfaction), mantıklılık (plausibility), anlaşılabilirlik (intelligibility), verimlilik (fruitfulness) olarak belirtilen dört şartın kavramsal değişimin gerçekleşebilmesi için yerine getirilmesi gerektiği savunulmaktadır (Akt, Kılıçoğlu, 2011:47).

Bu çalışmalar sonucunda çağ, estetik, fetih, gazâ, ıslahat ve iskân ile ilgili metinler oluşturulmuştur. (Ek:Çağ Kavramı Örneği) Oluşturulan metinlerde yer alan bilimsel bilgilerde ve verilen örneklerde hatalar olmaması için oluşturulan metinler Sosyal Bilgiler öğretmenlerine (10 kişi) okutularak görüşleri alınmıştır. Bu görüşler neticesinde metinler tekrar değerlendirilmiş ve metinler üzerinde çeşitli değişiklikler yapılmıştır.

Kavramsal değişim metinlerinin tekrar düzenlenmesinin ardından bu defa metinler deney ve kontrol grupları dışında olan ilköğretim 7. sınıf öğrencilerine (20 kişi) okutulmuştur. Öğrencilerden okudukları metinlerde anlamakta zorlandık- 
ları kısımları yazmaları, anlayamadıkları kelimeler varsa bunları işaretlemeleri istenmiştir. Öğrencilerden alınan görüşler doğrultusunda metinler üzerinde bazı düzeltmeler yapılmıştr. Bazı öğrenciler anlamadıkları kelimeler olduğunu, cümlelerin çok uzun olduğunu belirtirken, bazıları da görsel olarak daha fazla karikatür, fotoğraf benzeri görseller olmasını istediklerini ifade etmişlerdir. Bu doğrultuda metinler tekrar düzenlenmiş ve her bir kavram için bir adet olmak üzere toplamda 6 tane kavramsal değişim metnine son şekilleri verilmiştir.

\section{Verilerin analizi}

Araşttrmada elde edilen nicel verilerin çözümlenmesinde, SPSS (Statistical Package for the Social Sciences) 20 paket programı kullanılmış, sonuçlar 0.05 anlamlılık düzeyinde değerlendirilmiştir. Deney ve kontrol gruplarının öntest, sontest puanları hem kendi içlerinde hem de birbirleriyle karşılaştırılmıştı. Bu araştırmada, araştırmanın alt problemlerine uygun olarak yüzde, örnekleme alınan birey sayısı (n), aritmetik ortalama ile "bağımsız gruplar" için t-testi kullanılmıştır.

\section{Bulgular}

Araştırmanın birinci alt problemi "Çağ, estetik, fetih, gazâ, ıslahat ve iskân" kavramlarına ilişkin deney ve kontrol grubu öğrencilerinin mevcut kavram başarı testi öntest puanları arasında anlamlı bir fark var mıdır?" şeklinde ifade edilmiştir. Gruplardaki öğrencilerin öntest puanlarının karşılaştırılmasında kullanılacak teste karar vermek için öncelikle puanların normallik varsayımını karşılayıp karşılamadığını tespit etmek için grupların çarpıklık ve basıklık değerlerine bakılmıştir.

Tablo 4. Grupların Başarı Öntest Puanları İçin Tanımlayıcı İstatistikler

\begin{tabular}{lccccc}
\hline Grup & $\mathbf{n}$ & $\overline{\mathbf{x}}$ & $\mathbf{S}$ & Çarpıklık & Basıklık \\
\hline Deney & 22 & 16,63 & 7,84 & 1,054 & 0,723 \\
Kontrol & 27 & 14,25 & 6,22 & 0,608 & $-0,425$ \\
\hline
\end{tabular}

Tablo 4'te deney grubu çarpıklık değeri 1,054 basıklık değeri 0,723 olup kontrol grubu için ise çarpıklık değeri 0,608 basıklık değeri -0,425 arasındadır. Cameron (2004:544) normal dağılım için +2 ile -2 arasında değişiklik gösterebileceğini belirtilmiştir.

Tablo 5. Grup Değişkenine Göre Kavram Başarı Testi Öntest Puanlarının Farklılığı İçin t-testi Sonuçları

\begin{tabular}{ccccccc}
\hline Grup & $\mathbf{n}$ & $\overline{\mathbf{x}}$ & $\mathbf{S}$ & $\mathbf{s d}$ & $\mathbf{t}$ & $\mathbf{p}$ \\
Deney & 22 & 16,63 & 7,84 & & 1,184 & 0,242 \\
Kontrol & 27 & 14,26 & 6,22 & & \\
\hline
\end{tabular}

Deney ve kontrol grubu öğrencilerinin öntest puanlarının farklılığını belirlemek için t-testi yapılmıştır. Tablo 5 incelendiğinde araştırmaya katılan öğrencilerin Kavram Başarı Testinden aldıkları öntest başarı puanları grup değişkenine göre anlamlı bir farklılık göstermemiştir $[t(47)=1,184 ; p>0,05]$. Bu durum öğrencilerin ön bilgilerinin birbirine yakın olduğu şeklinde yorumlanabilir.

Tablo 6. Grupların Başarı Sontest Puanları İçin Tanımlayıcı İstatistikler

\begin{tabular}{cccccc}
\hline Grup & $\mathbf{n}$ & $\overline{\mathbf{x}}$ & $\mathbf{S}$ & Çarpıklık & Basıklık \\
Deney & 22 & 32,09 & 13,87 & 0,428 & $-1,034$ \\
Kontrol & 27 & 22,74 & 11,18 & 0,428 & $-0,366$ \\
\hline
\end{tabular}

Araştırmanın ikinci alt problemi “Çağ, estetik, fetih, gazâ, ıslahat ve iskân” kavramlarına ilişkin deney ve kontrol grubu öğrencilerinin kavram başarı testi sontest puanları arasında anlamlı bir fark var mıdır?' şeklinde ifade edilmiştir. Gruplardaki öğrencilerin sontest puanlarının karşılaştırı masında kullanılacak teste karar vermek için öncelikle puanların normallik varsayımını karşılayıp karşılamadığını tespit etmek için grupların çarpıklık ve basıklık değerlerine bakılmıştır. Tablo 6'da deney grubu çarpıklık değeri 0,428 basıklık değeri $-1,034$ olup kontrol grubu için ise çarpıklık değeri 0,428 basıklık değeri $-0,366$ arasındadır.

Tablo 7. Grup Değişkenine Göre Kavram Başarı Testi Sontest Puanlarının Farklılığı İçin t-testi Sonuçlar

\begin{tabular}{|c|c|c|c|c|c|c|}
\hline Grup & $n$ & $\overline{\mathbf{x}}$ & $S$ & sd & $t$ & $p$ \\
\hline Deney & 22 & 32,09 & 13,87 & 47 & 2614 & ר1000 \\
\hline Kontrol & 27 & 22,74 & 11,18 & $4 /$ & 2,614 & 0,012 \\
\hline
\end{tabular}


Tablo 7 incelendiğinde araştırmaya katılan öğrencilerin Kavram Başarı Testinden aldıkları sontest başarı puanları grup değişkenine göre anlamlı bir farklılık göstermiştir $[t(47)=2,614 ; p<0,05]$. Bu durum kavramsal değişim metinleri ve programa dayalı öğretim uygulamalarının öğrencilerin çă̆, estetik, fetih, gazâ, ıslahat ve iskân kavramlarına ait Kavram Başarı Testi puanlarını artırmada farklı etkilere sahip olduğunu göstermektedir. Başka bir anlatımla uygulanan deneysel işlemin bir sonucu olarak çağ, estetik, fetih, gazâ, ıslahat ve iskân kavramlarına ait Kavram Başarı Testi puanları değişmektedir. Öğrencilerin bu kavramlara ait Kavram Başarı Testi puanlarında gözlenen bu farklılıkların kavramsal değişim metinlerinden kaynaklandığı söylenebilir.

Tablo 8. Grupların Başarı Sontest Puanları İçin Tanımlayııı İstatistikler

\begin{tabular}{cccccc}
\hline Grup & $\mathbf{n}$ & $\overline{\mathbf{x}}_{\text {fark }}$ & $\mathbf{S}_{\text {fark }}$ & Çarpıklık & Basıklık \\
Deney & 22 & 15,46 & 8,57 & 0,801 & 0,306 \\
Kontrol & 27 & 8,46 & 7,90 & $-0,034$ & $-0,813$ \\
\hline
\end{tabular}

Araştırmanın üçüncü alt probleminde, deney ve kontrol grubu öğrencilerinin öntest-sontest puanlarının farklılığı araştrılmıştır. Gruplardaki öğrencilerin sontest puanlarının karşılaştrılmasında kullanılacak teste karar vermek için öncelikle puanların normallik varsayımını karşılayıp karşılamadığını tespit etmek için grupların çarpıklık ve basıklık değerlerine bakılmıştır. Tablo 8'de deney grubu farkı çarpıklık değeri 0,801 basıklık değeri 0,306 olup kontrol grubu farkı için ise çarpıklık değeri -0,034 basıklık değeri $-0,813$ arasındadır.

Tablo 9. Grup Değişkenine Göre Kavram Başarı Testi Öntest- Sontest Puanlarının Farklılığı İçin t-testi Sonuçları

\begin{tabular}{ccccccc}
\hline Grup & $\mathbf{n}$ & $\overline{\mathbf{x}}_{\text {fark }}$ & $\mathbf{S}_{\text {fark }}$ & sd & $\mathbf{t}$ & $\mathbf{p}$ \\
Deney & 22 & 15,46 & 8,57 & & & 0 \\
Kontrol & 27 & 8,46 & 7,90 & & 2,958 & 0,005 \\
\hline
\end{tabular}

Tablo 9 incelendiğinde araştırmaya katılan öğrencilerin Kavram Başarı Testinden aldıkları öntest- sontest başarı puanları arasındaki fark grup değişkenine göre anlamlı bir farklılık göstermiştir [t(47) 2,958; p<0,05].Deney grubunun puan farkı $\left(\bar{x}_{\text {fark }}=15,46\right)$ kontrol grubunun puan farkından $\left(\bar{x}_{\text {fark }}=8,46\right)$ daha fazladır. Bu durum çağ, estetik, fetih, gâzâ, ıslahat ve iskân kavramlarına ait Kavram Başarı Testi puanlarında deney öncesine göre daha fazla artış sağlayan kavramsal değişim metinlerinin, programa dayalı öğretime göre öğrencilerin bu kavramlara ait kavram yanılgılarını gidermede ve Kavram Başarı Testi puanlarını artırmada daha etkili olduğunu göstermektedir.

\section{Sonuçlar}

Eşitlenmemiş kontrol gruplu desene uygun olarak yürütülen çalışmada deney ve kontrol grubunda yer alan öğrencilere deneysel işlem öncesinde ve sonrasında çağ, estetik, fetih, gazâ, ıslahat ve iskân kavramlarıyla ilgili anlama düzeylerini ve yanılgılarını belirlemek amacıyla Kavram Başarı Testi uygulanmıştr.

Bu kavramlardan çağ, fetih, gazâ, ıslahat ve iskân kavramları programda geliştirme düzeyinde verilmişken estetik kavramı pekiştirme düzeyinde verilmektedir. Estetik kavramı diğer kavramlara göre daha üst düzeyde (pekiştirme) verildiği için bu kavramda kavram yanılgısının diğer kavramlara göre daha az olması ya da hiç olmaması gerekmektedir. Nitekim Akşit (2016) tarafindan yapılan çalışmada da iskân ve ıslahat kavramlarıyla ilgili yine gaza kavramıyla ilgili öğrencilerin ön bilgi ve algısının sınılı olması, Akşit ve Dinç (2015) tarafindan yapılan çalışmada ise iskân kavramıyla ilgili öğrencilerin herhangi bir ön bilgi ve algısı olmadığı çalışmadaki sonuçla benzerlik göstermektedir. Ancak Akşit (2016) ve Akgün (2014) tarafindan yapılan çalışmalarda fetih kavramıyla ilgili öğrencilerin ön bilgileri ve algılarının fazla olması çalışmadaki sonuçla farklılık göstermektedir. Bunun nedeni olarak kavram öğretiminde kavram aktarma düzeyine uygun olarak kavrama ilişkin gerekli açıklamaların yapılmamış olması gösterilebilir. Akgün (2014) tarafindan yapılan çalışmada ise gazâ, iskân, ıslahat ve estetik kavramlarına ilişkin öğrencilerde kavram yanılgısının olması çalışmanın sonuçlarıyla benzerlik göstermektedir.

Araştırmaya katılan öğrencilerin Kavram Başarı Testinden aldıkları sontest başarı puanları grup değişkenine göre anlamlı bir farklııı göstermiş olup bu durum kavramsal değişim metinleri ve programa dayalı öğretim uygulamalarının öğrencilerin çağ, estetik, fetih, gazâ, ıslahat ve iskân kavramlarına ait kavram başarı testi puanlarını artırmada farklı etkilere sahip olduğunu göstermektedir. Öğrencilerin bu kavramlara ait Kavram Başarı Testi puanlarında gözlenen bu farklılıkların kavramsal değişim metinlerinden kaynaklandığı söylenebilir.

Araştırmaya katılan öğrencilerin Kavram Başarı Testinden aldıkları sontest- öntest başarı puanları arasındaki fark grup değişkenine göre anlamlı bir farklıık göstermiştir. Deney grubunun puan farkı kontrol grubunun puan farkından daha fazladır. Bu sonuç kavramsal değişim metinlerinin öğrencilerin kavramlar hakkında sahip oldukları yanlış anla- 
maları ve tanımları gidermede etkili olduğunu göstermektedir. Aladağ ve Yılmaz (2014) tarafindan 4.sınıf ve Kılıçoğlu (2011) tarafindan 6.sınıf düzeyinde yapılan çalışmalarda da kavramsal değişim metinlerinin kavram yanılgılarını gidermede etkili olması çalışmanın sonucuyla benzerlik göstererek sonucu desteklemektedir. Makalede sayfa sınırlaması dolayısıyla bulgular bölümünde tablo olarak verilemeyen bulgulara ilişkin olarak aşağıdaki sonuçlara ulaşılmıştr:

"Çağ" kavramına yönelik olarak öğrencilerin çağı "dönem ve yüzyı" ile karıştırdıkları, çağ kavramını, "çağ’ın bölümleri, yazının bulunuşundan sonraki dönem ve $\mathrm{Hz}$. İsa'nın doğduğu gün" olarak düşündükleri belirlenmiştir. Öğrencilerin sontestte vermiş oldukları cevap ve gerekçelere göre ise kavram yanılgısının; 3. soruda deney grubunda \%40,9 düzeyinde kalırken kontrol grubunda \%59,3 düzeyinde olup; 15 . soruda deney grubunda $\% 46,5$ düzeyinde kalırken kontrol grubunda \% 63 düzeyinde olup; 21 . soruda deney grubunda \% 18,2 düzeyinde kalırken kontrol grubunda $(\% 44,4)$ düzeyinde olduğu görülmektedir. Bu durum çağ kavramıyla ilgili hazırlanan kavramsal değişim metinlerinin bu kavrama ilişkin yanılgıları ortadan kaldırmada etkili olduğunu göstermektedir.

"Estetik" kavramına yönelik olarak öğrencilerin estetiğe ait özellikleri "tarihi ve coğrafi özellikler" ve estetik kavramını "hoşgörü ve yardımlaşma" kavramları ile karıştırdıkları belirlenmiştir. Öğrencilerin sontestte vermiş oldukları cevap ve gerekçelere göre ise kavram yanılgısının; 5 . soruda deney grubunda $\% 40,9$ düzeyinde kalırken kontrol grubunda $\% 48,2$ düzeyinde olup; 12 . soruda deney grubunda $\% 54,6$ düzeyinde kalırken kontrol grubunda $\% 63$ düzeyinde olup; 18. soruda deney grubunda $\% 40,9$ düzeyinde kalırken kontrol grubunun da $\% 44,5$ düzeyinde olup; 24 . soruda deney grubunda \%59,1 düzeyinde gerçekleşirken kontrol grubunda $\% 48,2$ düzeyinde olduğu görülmektedir. 24 . soruda deney grubu öğrencileri, kontrol grubu öğrencilere göre daha fazla yanlış cevap vermiş olmalarına rağmen çok daha fazla bir düzeyde doğru gerekçe ileri sürebilmişlerdir. yanlış cevap-doğru gerekçe kategorisinde deney grubunda \%31,8 düzeyinde gerçekleşirken, kontrol grubunda ise \%3,7 düzeyinde olduğu görülmektedir. Bu durum çağ kavramıyla ilgili hazırlanan kavramsal değişim metinlerinin bu kavrama ilişkin yanılgıları ortadan kaldırmada etkili olduğunu göstermektedir. Akgün(2014) tarafindan yapılan çalışmada en çok kavram yanılgısının estetik değerinde olması da çalışmanın sonucu ile benzerlik göstermektedir.

"Fetih" kavramına yönelik olarak bazı öğrenciler "toprak almak, savaş kazanmak, işgal etmek, istila etmek" olarak ifade ederken, bazılarınınsa fetih kavramını "bir yeri kendi himayesine almak, bir yeri gezmek görmek ya da yeni şeyler öğrenmek" olarak değerlendirdikleri belirlenmiştir. Öğrencilerin fetih kavramını en çok "işgal etmek ve istila etmek" ile karıştırdıkları belirlenmiştir. Öğrencilerin sontestte vermiş oldukları cevap ve gerekçelere göre ise kavram yanılgısının; 4. soruda deney grubunda $\% 54,6$ düzeyinde kalırken kontrol grubunda $\% 63$ düzeyinde olup; 7 . soruda deney grubunda $\% 59,1$ düzeyinde kalırken kontrol grubunda $\% 70,4$ düzeyinde olup; 11 . soruda deney grubunda $\% 72,7$ düzeyindeyken kontrol grubunda \% 66,7 düzeyinde olup; 19. soruda deney grubunda $\% 27,3$ düzeyinde kalırken kontrol grubunda \% 48,2 düzeyinde olduğu görülmektedir.

"Gâzâ" kavramına yönelik olarak öğrencilerden bazıları, gâzâ kavramını "kaza yapmak, ölüm ve kazanmak " olarak ifade ederken, bazılarının da gâzâyı daha çok "iki aracın birbirine çarpması ya da bir ilin ilçesi" olarak değerlendirdikleri belirlenmiştir. Öğrencilerin sontestte vermiş oldukları cevap ve gerekçelere göre ise kavram yanılgısının; 1 . soruda deney grubunda $\% 22,7$ düzeyinde kalırken kontrol grubunda \% 51,9 düzeyinde olup; 6 . soruda deney grubunda $\% 40,9$ düzeyinde kalırken kontrol grubunda \% 55,6 düzeyinde olup; 10 . soruda deney grubunda $\% 40,9$ düzeyinde kalırken kontrol grubunda \% 70,4 düzeyinde olup; 16 . soruda deney grubunda $\% 59,1$ düzeyindeyken kontrol grubunda $\% 85,2$ düzeyinde olup; 23 . soruda deney grubunda $\% 50$ düzeyindeyken kontrol grubunda $\% 66,7$ düzeyinde olup; 25 . soruda deney grubunda \%59,1 düzeyindeyken kontrol grubunda \% 44,4 düzeyinde olduğu görülmektedir. Buna rağmen 25. soruda yanlış cevap doğru gerekçe kategorisinde deney grubundaki öğrencilerin \% 22,7'si doğru gerekçe belirtebilmişlerdir. Kontrol grubunda ise hiçbir öğrenci doğru gerekçe belirtememiştir.

"Islahat" kavramına yönelik olarak öğrencilerin ıslahat kavramını "iç karışıklık" olarak anladıkları belirlenmiştir. Öğrencilerin sontestte vermiş oldukları cevap ve gerekçelere göre ise kavram yanılgısının; 8. soruda deney grubunda $\% 68,2$ düzeyinde kalırken kontrol grubunda $\% 77,8$ düzeyinde olup; 14 . soruda deney grubunda $\% 68,2$ düzeyindeyken kontrol grubunda \% 63 düzeyinde olup; 20. soruda deney grubunda \%25,9 düzeyindeyken kontrol grubunda \% 22,8 düzeyinde olduğu görülmektedir.

"İskan" kavramına yönelik olarak bazı öğrencilerin "otorite, siyasi birlik, hoşgörü ve adalet ile denge" olarak değerlendirdikleri belirlenmiştir. Öğrencilerin iskân kavramını en çok "tımar" ile karıştrdıkları görülmüştür. Öğrencilerin sontestte vermiş oldukları cevap ve gerekçelere göre ise kavram yanılgısının; 2 . soruda deney grubunda \% 68,2 düzeyindeyken kontrol grubunda \% 62,9 düzeyinde olduğu görülmektedir. Buna rağmen yanlış cevap doğru gerekçe kategorisinde deney grubundaki öğrencilerin \% 40,9'u doğru gerekçe belirtebilmişlerdir. Kontrol grubunda ise doğru gerekçe belirtme oranı \% 22,2 olarak gerçekleşmiştir. Bu sonuca göre deney grubundaki öğrenciler kontrol grubundaki öğrencilere göre 
daha fazla doğru gerekçe belirtmişlerdir. Kavram yanılgısı 9. soruda deney grubunda $\% 54,5$ düzeyinde kalırken kontrol grubunda \% 77,8 düzeyinde olup; 13 . soruda deney grubunda $\% 45,4$ düzeyinde kalırken kontrol grubunda $\% 55,6$ düzeyinde olup; 17 . soruda deney grubunda $\% 27,3$ düzeyinde kalırken kontrol grubunda $\% 63$ düzeyinde olup; 22 . soruda deney grubunda \%36,4 düzeyinde kalırken kontrol grubunda \% 51,9 düzeyinde olup; 26 . soruda deney grubunda \%50 düzeyinde kalırken kontrol grubunda \% 55,6 düzeyinde olduğu görülmektedir.

\section{5. Öneriler}

Araştırmanın sonuçlarına dayalı olarak önemli görülen aşağıdaki öneriler sunulmuştur.

$\checkmark \quad$ Kavramsal değişim metinleri ile ilgili çalışmalar incelendiğinde özellikle fen bilimlerinde yoğunlaşma olduğu görülmektedir. Sosyal Bilimler alanında da kavram öğretiminde kavramsal değişim metinlerinin kavramların öğretimine etkisi incelenebilir.

$\checkmark \quad$ Kavramsal değişimin oluşmasında öğrencilerin hazır bulunuşluk durumları oldukça önemlidir. Dolayısıyla derse başlanmadan önce çok basit bir kaç yöntem (soru cevap, tartı̧ma vb.) kullanılarak kavram yanılgıları açığa çıkarılıp ve bu yanılgıları gidermeye yönelik etkinlik ve planlamalar yapılabilir.

$\checkmark$ Öğrencilerin Sosyal Bilgiler derslerinde anlamakta zorlandıkları kavramlar bulunmaktadır. Kavram yanılgılarıın ortaya çıkarılmalarında ve giderilmelerinde, öğrencilerin anlamakta zorlandıkları kavramları doğru ve kalıcı bir şekilde öğrenmelerinin sağlanmasında, kavramsal değişim metinlerinin kullanımının faydalı olacağı düşünülmektedir.

\section{Kaynakça}

Akgün, i.H. (2014) Sosyal Bilgiler Dersi 7. Sınıf Kültür ve Miras Öğrenme Alanı Türk Tarihinde Yolculuk Ünitesinde Geçen Kavramların Öğrenilme Düzeyi. Turkish Studies - International Periodical For The Languages, Literature And History Of Turkish Or Turkic. 9 (5), 105-116.

Akşit, İ ve Dinç, E. (2015). Sosyal Bilgiler Dersinde İskân Kavramının Öğretimi Üzerine Bir Eylem Araşttrması. Uşak Üniversitesi Eğitim Araştırmaları Dergisi, 1(1), 78-87

Akşit, ì. (2016). 7. Sınıf Sosyal Bilgiler Dersi Türk Tarihinde Yolculuk Ünitesinde Geçen Bazı Kavramların Öğrenilmesi Sürecinde Karşılaşılan Sorunların Belirlenmesi ve Çözümüne Yönelik Bir Eylem Araştırması. (Yayımlanmamış Doktora Tezi).Uşak Üniversitesi/ Sosyal Bilimler Enstitüsü, Uşak.

Aladağ, S. ve Yılmaz, E.(2014). Kavramsal Değişim Metinlerinin Öğrencilerin Sosyal Bilgiler Dersindeki Kavram Yanılgılarını Gidermeye Etkisi. Trakya Üniversitesi Sosyal Bilimler Dergisi, 16 (2), 163-176

Alkış, S. (2014) Sosyal Bilgilerde Kavram Öğretimi. M. Safran (Ed.), Sosyal Bilgiler Öğretimi (70-89), Ankara: Pegem

Arıkurt, E. (2014) Kavram Karikatürlerinin ve Kavramsal Değişim Metinlerinin Ortaokul 7. Sınıf Öğrencilerinin Başarılarına, Kavramsal Değişimlerine Ve Tutumlarına Etkisinin Karşılaştırılması. (Yayımlanmamış Yüksek Lisans Tezi). Giresun Üniversitesi/Fen Bilimleri Enstitüsü, Giresun.

Ay, Ö. (2011). Illköğretim 8. Sınıf Fen ve Teknoloji Dersi 'Maddenin Halleri ve Isı' Ünitesinde Belirlenen Kavram Yanılgılarının Giderilmesinde Kavramsal Değişim Metinleri Kullanımının Etkisi ve Öğrenci Görüşleri. (Yayımlanmamış Yüksek Lisans Tezi). Hacettepe Üniversitesi/Sosyal Bilimler Enstitüsü, Ankara.

Baloğlu, N. (2003). Ilköğretim 6. Sınıf Öğrencilerinin Dünya Ve Evren Konusu Ile Ilgili Kavram Yanılgılarının Tespiti Ve Bu Kavram Yanılgıları Üzerinde Öğretmen Tutum Ve Davranışlarının Etkisi. (Yayımlanmamış Yüksek Lisans Tezi). Gazi Üniversitesi/ Eğitim Bilimleri Enstitüsü, Ankara.

Borazan, İ. (2008). Kavram Yanılgısı ve Çoklu Zekâ Alanlarının Ilişkilendirilmesine Dayalı Bir Öğretimin Kavram Yanılgılarının Giderilmesine Etkisinin Incelenmesi. (Yayımlanmamış Yüksek Lisans Tezi). Balıkesir Üniversitesi/ Fen Bilimleri Enstitüsü, Balıkesir.

Cameron, A. (2004). Kurtosis. M.Lewis-Beck,A.Bryman and T.Liao (Ed.) Encyclopedia of Social Science Research Metodhs. (pp. 544-545) Thousand Oaks,Ca: Sage

Çaycı, B. (2007). Kavram Öğreniminde Kavramsal Değişim Yaklaşımının Etkililiğinin Incelenmesi. (Yayımlanmamış Doktora Tezi). Gazi Üniversitesi/Eğitim Bilimleri Enstitüsü, Ankara.

Çaycı, B. (2009). Hayat Bilgisi Öğretiminde Kavram Öğretimi. B. Tay (Ed.), Hayat Bilgisi Öğretimi, (303-.329) Ankara: Maya.

Demirci, Ö. (2011) 8. Sınıf Öğrencilerinin Asitler ve Bazlar Konusuyla Ilgili Yanılgılarını Gidermede Animasyon Destekli Kavramsal Değişim Metinlerinin Etkililiğinin Araştırılması. (Yayımlanmamış Yüksek Lisans Tezi). Karadeniz Teknik Üniversitesi/Eğitim Bilimleri Enstitüsü, Trabzon.

Doğanay, A. (2005). Öğretimde Kavram ve Genellemelerin Geliştirilmesi. C, Öztürk ve D, Dilek (Ed.), Hayat Bilgisi ve Sosyal Bilgiler Öğretimi ( 265-296). Ankara: Pegem A.

Elvan, Ö. (2012). Sosyal Bilgiler Öğretiminde Çalışma Yaprakları Kullanılmasının Kavram Yanılgılarını Gidermeye Etkisi. (Yayımlanmamış Yüksek Lisans Tezi). Ahi Evran Üniversitesi/Sosyal Bilimler Enstitüsü, Kırşehir. 
Eyidoğan, F. ve Güneysu, S. (2002). Ilköğretim 8. Sınıf Fen Bilgisi Kitaplarındaki Kavram Yanılgılarının Incelenmesi. V. Fen Bilimleri ve Matematik Eğitimi Kongresi, Ankara.

Hacımustafaoğlu, M. (2015). Ortaokul 8. Sınıf Öğrencilerinin "Maddenin Halleri ve Isı” Ünitesinde Kavramsal Değişim Sağlamalarında Farklı Kavramsal Değişim Yöntem ve Tekniklerle Zenginleştirilmiş Rehber Materyallerin Etkisi. (Yayımlanmamış Yüksek Lisans Tezi). Giresun Üniversitesi/ Fen Bilimleri Enstitüsü, Giresun.

Karasar, N. (2008). Bilimsel Araştırma Yöntemi. Ankara: Nobel.

Karataş, F. Ö., Köse, S. ve Coştu, B. (2003). Öğrenci Yanılıılarını ve Anlama Düzeylerini Belirlemede Kullanılan İki Aşamalı Testler. Pamukkale Üniversitesi Eğitim Fakültesi Dergisi, 13 (1), 54-69.

Kılıç Alemisoğlu, Ö. (2014) illköğretim 7. Sınıf Öğrencilerinin Karışımlar Konusundaki Kavram Yanılgılarının Belirlenmesi ve Giderilmesinde Kavram Değişim Metinlerinin Etkisi. (Yayımlanmamış Yüksek Lisans Tezi). Ondokuz Mayıs Üniversitesi/ Eğitim Bilimleri Enstitüsü, Samsun.

Kılıçoğlu, G. (2011). Sosyal Bilgiler Derslerinde Kavramsal Değişim Metinlerinin Kavram Yanılgılarını Giderme Üzerine Etkisi. (Yayımlanmamış Doktora Tezi). Gazi Üniversitesi/ Eğitim Bilimleri Enstitüsü, Ankara.

Mutlu, Y. (2011) İlköğretim 8. Sınıf Öğrencilerinin Elektrik Konusundaki Kavramsal Gelişim Süreçlerinin Incelenmesi. (Yayımlanmamış Yüksek Lisans Tezi). Yüzüncü Yıl Üniversitesi/ Fen Bilimleri Enstitüsü, Van.

Özdemir, A. M. (2012) IIlköğretim 5. Sınıf Fen ve Teknoloji Dersi Ünitelerinde Kavramsal Değişim Yaklaşımının Öğrenci Başarısına Etkisinin Incelenmesi. (Yayımlanmamış Doktora Tezi). Gazi Üniversitesi/ Eğitim Bilimleri Enstitüsü, Ankara.

Sarı Ay, Ö. (2011) Ilköğretim 8. Sınıf Fen Ve Teknoloji Dersi 'Maddenin Halleri ve Isı' Ünitesinde Belirlenen Kavram Yanılgılarının Giderilmesinde Kavramsal Değişim Metinleri Kullanımının Etkisi ve Öğrenci Görüşleri. (Yayımlanmamış Yüksek Lisans Tezi). Hacettepe Üniversitesi/Sosyal Bilimler Enstitüsü, Ankara.

Sever, R. Mazman Budak, F. ve Yalçınkaya, E. (2009). Coğrafya Eğitiminde Kavram Haritalarının Önemi. Atatürk Üniversitesi Sosyal Bilimler Enstitüsü Dergisi, 13 (2), 19-32.

Türk Dil Kurumu [TDK], (2016). http://www.tdk.gov.tr/index.php?option=com_bts

Topuz, N. (2014) Kavramsal Değişim Yaklaşımı ve Iş̧birlikli Öğrenmenin, Öğrencilerin Fen Başarısına, Fen Dersine Karşı Tutumlarına ve Kavramları Günlük Yaşamla ilişskilendirebilme Düzeylerine Etkisi. (Yayımlanmamış Yüksek Lisans Tezi). Trakya Üniversitesi/ Fen Bilimleri Enstitüsü, Edirne.

Yazıcı, H. ve Samancı, O. (2003). İlköğretim Öğrencilerinin Sosyal Bilgiler Ders Notları İle İlgili Bazı Kavramları Anlama Düzeyleri. Milli Eğitim Dergisi, sayı:158.

Yılmaz, Z. A. (2010). Kavramsal Değişim Metinlerinin Üniversite Öğrencilerinin Geometrik Optik Konusundaki Kavram Yanılgılarının Düzeltilmesi ve Fizik Dersine Karşı Tutumlarının Incelenmesi, (Yayımlanmamış Doktora Tezi), Atatürk Üniversitesi Fen Bilimleri Enstitüsü/ Fen Bilimleri Enstitüsü, Erzurum. 